\title{
Platelet Storage Temperature - How Low Can We Go?
}

\author{
Emma C. Josefsson John H. Hartwig Karin M. Hoffmeister \\ Translational Medicine Division, Department of Medicine, Brigham and Women's Hospital, \\ Harvard Medical School, Boston, MA 02115, USA
}

\section{Key Words}

Hematology · Platelet storage - Platelet transfusion · Platelets

\section{Summary}

Transfusion of human platelets, stored in blood banks as concentrates, is the treatment of choice for thrombocytopenia and bleeding. To be clinically effective, transfused platelets must circulate and retain sufficient function to recognize and react to vascular damage. Storage at room temperature is limited to 5-7 days because of the risk of bacterial growth and loss of platelet functionality, as platelets do not tolerate refrigeration. Once chilled, platelets are detected and rapidly removed from circulation despite high functionality. We recently defined a clearance mechanism for short-term (2 h) refrigerated platelets: $\alpha_{M} \beta_{2}$ receptors on hepatic macrophages recognize clustered $\beta \mathrm{GICNAc}$ residues on platelet GPIb $\alpha$ receptors on refrigerated platelets. Here we review current knowledge of the mechanisms of platelet removal, the changes that occur in platelets after short and extended refrigeration, and methods to preserve platelet concentrates long-term for transfusion.

\section{Introduction}

Platelets maintain vascular integrity, prevent spontaneous bleeding, and work in concert with blood coagulation proteins to limit blood leakage following tissue damage. Bleeding due to thrombocytopenia is a major cause of morbidity in clinical

\begin{tabular}{ll}
\hline KARGER & ( 2007 S. Karger GmbH, Freiburg \\
Fax +49 761 45207 14 & Accessible online at: \\
$\begin{array}{l}\text { E-mail Information@Karger.de } \\
\text { www.karger.com }\end{array}$ & www.karger.com/tmh
\end{tabular}

Translational Medicine Division, Brigham and Women's Hospital

One Blackfan Circle, CHRB 6th floor, Boston, MA 02115, USA

Tel. +1 61735590-10, Fax -16

www.karger.com

E-mail khoffmeister@rics.bwh.harvard.edu.

Schlüsselwörter

Hämatologie · Thrombozyten-Lagerung ·

Thrombozyten-Transfusion - Thrombozyten

\section{Zusammenfassung}

Die Transfusion von Humanthrombozyten, in Blutbanken als Konzentrate gelagert, sind das Mittel der Wahl für die Behandlung bei Thrombozytopenie und Hämorrhagie. Um klinisch wirksam sein zu können, müssen transfundierte Plättchen zirkulieren und eine ausreichende Funktion aufrechterhalten, um Gefäßschäden zu erkennen und darauf zu reagieren. Die Lagerung bei Raumtemperatur ist auf 5-7 Tage begrenzt wegen der Gefahr des Wachstums von Bakterien und des Funktionsverlustes; Plättchen vertragen keine Abkühlung. Einmal abgekühlte Thrombozyten werden erkannt und trotz ihrer erhaltenen Funktion sofort aus der Zirkulation entfernt. Wir haben kürzlich einen Eliminationsmechanismus für kurzzeitig (2 h) gekühlte Plättchen vorgeschlagen: Im Falle gekühlter Thrombozyten erkennen $\alpha_{M} \beta_{2}$-Rezeptoren auf LeberMakrophagen Cluster aus $\beta$ GlcNAc-Resten der PlättchenGPIb $\alpha$-Rezeptoren. In dieser Übersichtsarbeit stellen wir den derzeitigen Kenntnisstand zur Plättchenelimination, den Veränderungen nach kurzer oder langer Abkühlung sowie den Methoden für eine Langzeithaltbarmachung von Thrombozyten zur Transfusion vor.

disorders such as sepsis, cancer, and preeclampsia. Platelet transfusion remains the sole replacement therapy for patients having active bleeding. Although the development of platelet storage techniques has permitted millions of transfusions per year, current blood banking practice for platelets is far from ideal. Platelets for transfusion are stored in gas-permeant bags 
at room temperature, on large shaking racks, for $\leq 5$ days, a limit imposed by the risk of bacterial growth in the bags. Other major problems associated with room temperature platelet storage are viral and bacterial contamination [1], the loss of platelet functionality [2], and the complexity of managing supply with demand. New technologies such as bacterial detection $[3,4]$, or pathogen inactivation [5] to reduce bacterial growth, might ultimately aid the blood banker in dealing with these potential problems. For example, current apheresis platelets have fewer significant storage lesions than products used years ago, mainly due to improvements in the materials and methods used in platelet storage and collection. Furthermore, platelet additive solutions (PAS) may prove beneficial in better preserving platelet properties during 5- and possibly 7-day storage [6-9]. Platelet refrigeration can dramatically reduce the risk of bacterial growth [10] and preserve platelet function $[11,12]$, thereby permitting extended storage of platelets and bolstering product inventories. However, almost 40 years ago, Murphy and Gardner [13] demonstrated that refrigerated, transfused human platelets are rapidly cleared from the circulation, showing that platelets stored at room temperature $\left(22^{\circ} \mathrm{C}\right)$ circulated significantly longer with a typical life span of 7-9 days versus 2-4 days for refrigerated platelets.

This review addresses our current knowledge of the mechanisms of platelet removal, changes that occur in the surface of platelets at room temperature and after short and extended refrigeration, methods to preserve platelet concentrates longterm, and the necessity for robust models to study in vivo efficacy of the stored platelet product. Our studies on the mechanisms of platelet clearance following refrigeration have suggested approaches to improve the circulation of these platelets.

\section{Room Temperature versus Refrigerated Storage}

To have clinical utility, transfused platelets must both circulate and retain sufficient function such that they recognize and react to vascular damage. Clinically, the success of platelet transfusion is judged solely by an increase in the circulating platelet count. Platelet circulation in vivo is evaluated after the infusion of radiolabeled platelets that can be identified and followed with time in blood $[14,15]$. However, the ability of transfused platelets to circulate in vivo, fails to provide their 'level' of function. At present, we lack measures for platelet function in vivo and have only a superficial understanding of factors that dictate platelet survival and/or initiate platelet clearance.

Platelet lifespan is defined by an intrinsic apoptotic mechanism [16]. Mason et al. [16] have provided evidence in mice that the pro-survival Bcl-XL protein constrains the pro-apoptotic activity of Bak to maintain platelet survival; e.g., mouse platelets lacking Bcl-XL have short survivals compared to normal, while platelets from mice engineered to lack Bak sur- vive considerably longer. In accordance with this finding, platelets 'aged' in vitro to induce caspase activation are removed rapidly from the circulation [17]. Phosphatidylserine (PS) exposure is believed to be the ultimate death signal in this pathway directly initiating platelet recognition and clearance by the phagocytic system [18-21]. Storing platelets at room temperature would not be expected to slow this lifespan clock, and accordingly, activated caspase-3 levels and PS exposure increase as platelets age at room temperature [19, 22, 23]. Refrigeration of human platelet concentrates, however, prevents PS exposure [11] suggesting that it slows the intrinsic apoptotic clock and thereby would permit long-term storage. Sialylation, the addition of a terminal sialic acid to glycans, functions as an anti-clearance signal for blood cells and serum proteins, shielding the exposure of underlying immature carbohydrate epitopes such as galactose, GalNAc, and GlcNAc, ligands recognized by scavenger receptors [24-26]. For example, the sialic acid content of erythrocytes decreases as they age in blood suggesting that desialylation is a physiological trigger for clearance [25]. Also, treatment of erythrocytes with neuraminidase in vitro to enzymatically remove sialic acid unmasks penultimate $\beta$-galactose moieties and initiates erythrocyte removal through the macrophage asialoglycoprotein receptor (ASGPR) [27]. A similar mechanism may be at work to modulate platelet survival. Platelets lose sialic acid from their membrane glycoproteins as they age [28, 29], and, like erythrocytes, in vitro desialylated platelets are cleared rapidly [30, 31]. Mice deficient in the sialyltransferase ST3GalIV [32], an enzyme responsible for sialylation of certain galactose residues, have low platelet counts most likely because of accelerated platelet clearance due to their high density of exposed galactose residues. Moreover, platelets stored at room temperature progressively lose sialic acid [33]. Therefore, we conclude that carbohydrate density and/or its presentation can alter platelet survival.

Since room temperature-stored platelets remain metabolically active, they progressively lose viability and function, a phenomenon known as the 'platelet storage lesion' [34, 35]. Accumulation of lactate from platelet metabolism decreases the $\mathrm{pH}$ of concentrates, and $\mathrm{pH}$ levels below 6.0 are associated with loss of platelet viability. Platelet refrigeration greatly reduces lactate production $[11,12]$.

Platelets also slowly become activated when stored at room temperature for prolonged times [36]. The effect of refrigeration on platelet activation remains controversial. Some investigators have reported the presence of increased platelet activation markers such as exposure of surface P-selectin [11, 37, 38] following refrigeration, indicating that platelet refrigeration can induce some $\alpha$-granule release. However, other investigators have reported the opposite, that refrigeration ( $<21$ days) retards the release of $\alpha$-granule contents such as $\beta$-thromboglobulin $[12,39,40]$. Refrigerated platelets spontaneously form aggregates [41, 42], respond better to agonists than room temperature platelets [11, 43-51], and adhere bet- 
ter to von Willebrand factor (vWf) under shear stress $[52,53]$. Furthermore, a recent study shows that systemic hypothermia of $31-34{ }^{\circ} \mathrm{C}$ in mice accelerates thrombus formation in arterioles and venules [43], indicating that exposure to temperatures below the physiological norm may activate platelets in vivo. Critically, platelet activation per se does not induce platelet clearance since platelets treated with agonists in vitro circulate normally when transfused into primates or mice [54, 55]. Furthermore, we have demonstrated that galactosylated platelets circulate normally after refrigeration in mice, despite acquiring spiky shapes [56]. At face value, these findings appear to eliminate a central role for platelet shape change and/or P-selectin upregulation, in the clearance of stored platelets. Conversely, obtainment of a discoid shape is not a requirement for normal platelet survival, as $\beta 1$-tubulin lacking transgenic platelets, which have amorphic shapes, circulate normally [57]. In conclusion, there seems little value in assessing discoid shape of stored platelets as evidence of platelet viability in the clinical setting.

The response of platelets to hypotonic shock is another test reported to be predictive of platelet viability following storage. It measures the ability of platelets to recover from a hypotonic challenge with the notion that only 'metabolically fit' platelets recover. Since refrigerated platelets perform poorly in this assay [12], investigators have proposed that refrigeration impairs platelet adenosine triphosphate (ATP) production $[58,59]$. It has also been reported that exposure of platelets to low temperatures can induce mitochondrial damage $[60,61]$ providing a mechanism for altered ATP metabolism. However, clinical studies have demonstrated clearly that refrigerated ( $<2$ days) platelets are hemostatically effective when transfused into humans [45, 62-67].

The major problem with storing and using refrigerated platelets remains their shortened lifespan. This phenomenon is not restricted to humans and is shared by other mammalian platelets that have been studied in baboon, rabbit, and mouse models [37, 38, 56, 68-73]. Since experimental therapy is limited by technical and ethical considerations in humans, studies in animals remain the best option for understanding this phenomenon. Historically, nonhuman primates have been used for in vivo studies of platelets. The main advantages of nonhuman primates are the similarity of their platelets to those of humans, in terms of survival times, in vitro function, and blood counts, and the fact that sufficient blood can be obtained to mimic human storage conditions [55, 74-78]. Unfortunately, studies in nonhuman primates are constrained by their high cost and limited availability. Although platelets from other mammals share the sensitivity to cold, differences in platelet half-lives and immune systems add complexity to their use. One approach that has been promoted is the transfusion of human platelets into animals, but it results in rapid platelet removal unless the animals are deprived of the bulk of their phagocytic system $[69,70,79,80]$. For example, human platelets are tolerated in rabbits suppressed with ethyl palmitate, but the utility of platelet survival under these conditions compared to normal is unclear. Using animals with an adaptive humanized immune system [81] could be an approach for future survival and functional studies of transfused human platelets. Dogs have been used to study fluorescently labeled rehydratedlyophilized platelet incorporation into wounds by fluorescent microscopy [82], and the use of porcine platelets has been proposed for studies of cold-induced activation of platelets [83]. However, few in vivo platelet studies are reported in pigs [84, 85]. Murine transfusion models have been used to dissect platelet clearance mechanisms $[17,56]$. Murine platelet storage is complicated because of the small volume of platelets obtainable from mice although anti-mouse platelet-specific antibodies and genetically altered mice are widely available. At present, we lack assays evaluating platelet function in vivo.

\section{Clearance of Short-Term Refrigerated Platelets}

An effort to address the clinically relevant problem of why refrigerated platelets fail to circulate led us to define a previously unsuspected, carbohydrate-dependent platelet clearance mechanism. The macrophage carbohydrate-binding $\alpha_{M} \beta_{2}$ recognizes clustered GPIb $\alpha$ subunits of the vWf receptor (vWfR) complex following short-term refrigeration, resulting in the phagocytosis and clearance of platelets in vivo in mice and in vitro by human THP-1 macrophages [37, 56, 86, 87]. Experiments using $\alpha_{M} \beta_{2}$-deficient but not vWf-, complement- or P-selectin-deficient mice [54], markedly improved the survival of refrigerated platelets. Removal of GPIbo's ligand bindingdomain using the O-sialoglycoprotein endopeptidase restored the circulation of refrigerated murine wild-type platelets indicating that the external domain of GPIb $\alpha$ initiates clearance [37]. Subsequent work narrowed carbohydrate recognition by $\alpha_{M} \beta_{2}$ to exposed $\beta$ GlcNAc ( $\beta-N$-acetylglucosamine) residues on N-linked GPIb $\alpha$ glycans (fig. 1) [56, 86]. GPIb $\alpha$-associated $\mathrm{N}$-linked glycans are complex-type, branched carbohydrates covalently attached to asparagine residues. When completely assembled, they are capped by sialic acid. Removal of sialic acid (desialylation) exposes galactose and degalactosylation reveals $\beta$ GlcNAc. The exposure of individual sugars is detectable by their binding to specific lectins, e.g., ricinus communis agglutinin (RCA) I binds galactose and succinylated wheat germ agglutinin (sWGA) binds $\beta$ GlcNAc. Although resting platelets bind some sWGA, refrigerated platelets have markedly increased binding suggesting that altered epitope presentation of exposed $\beta$ GlcNAc on GPIb $\alpha$ can facilitate lectin binding to refrigerated platelets. Since altered presentation correlates with a clustering of GPIb $\alpha$ on the surface of refrigerated platelets, we believe clustering is the cause of increased lectin recognition $[37,56]$. The $\beta$ GlcNAc residues recognized by $\alpha_{M} \beta_{2}$ represent either incomplete glycan processing on platelets or result from a degradative process that occurs in blood. In an attempt to remedy their poor circula- 
Fig. 1. Proposed mechanisms for cold-induced platelet clearance. The von Willebrand factor receptor (vWfR) complex, specifically GPIb $\alpha$, have complete (sialic acid-capped) and incomplete $\mathrm{N}$-linked glycans with exposed $\beta$ GlcNAc and/or galactose residues. Clustering of vWfRs and exposed $\beta$-GlcNAc initiate phagocytosis by the macrophage $\alpha_{M} \beta_{2}$ integrin. Coverage of exposed $\beta$-GlcNAc residues by galactose (galactosylation) prevents phagocytosis of short-term refrigerated platelets, but not of long-term refrigerated platelets. Extended refrigeration maybe followed by additional surface changes such as 'hyperclustering' of receptors and their associated glycans and loss of receptors and/or carbohydrate residues. This leads to phagocytosis by a $\alpha_{M} \beta_{2}$ integrinindependent mechanism, perhaps through galactose receptors and/or scavenger receptors.

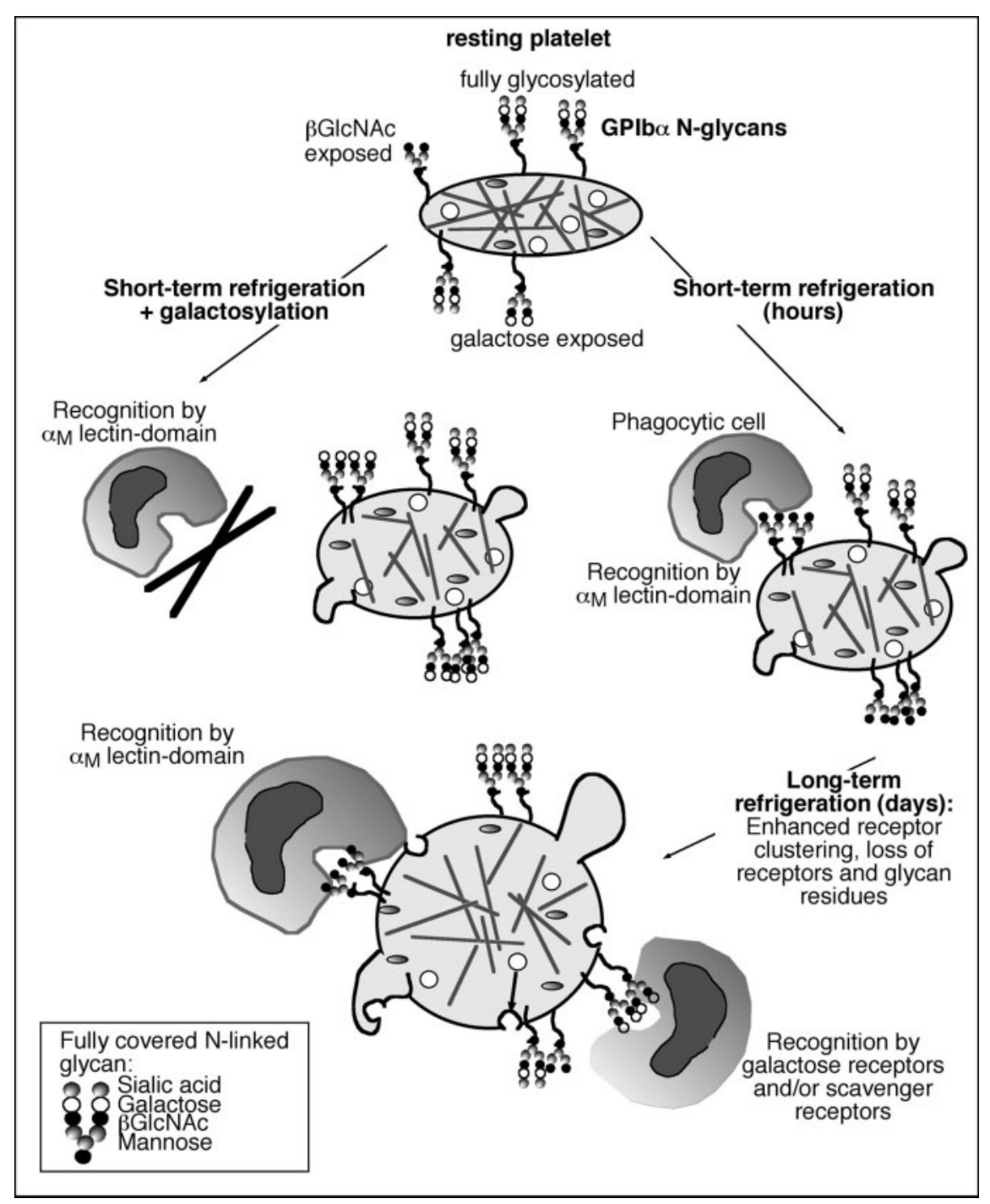

tion, we galactosylated refrigerated platelets and were surprised to learn that both human and murine platelets have functional platelet galactosyltransferase(s) on their surface. These enzyme(s) respond to the simple addition of UDPgalactose by transferring galactose onto exposed $\beta$ GlcNAc residues of human or mouse GPIb $\alpha$ [56]. Galactosylation markedly improved the survival of murine platelets refrigerated for $2 \mathrm{~h}$ [56]. In support of this finding, other investigators have demonstrated that platelet galactosylation prolongs the survival of long-term refrigerated human or rabbit platelets following the transfusion into rabbits [70, 71]. Subsequent experiments, however, showed that galactosylation was not beneficial in improving the circulation of 48 h-refrigerated platelets in humans [88]. While depriving the $\alpha_{M} \beta_{2}$ lectin-domain of its $\beta$ GlcNAc ligand on refrigerated platelets, galactosylation theoretically provides a new ligand for asialoglycoprotein receptors (ASGPR). Hence, it was surprising that refrigerated mouse platelet circulation could be improved by galactosylation. We postulated that the number of exposed $\beta$ GlcNAc residues on GPIb $\alpha$ was small, such that even after clustering and galactosylation, the galactose density was insufficient to engage galactose-recognizing lectins [56]. However, this theory does not account for the recognition of long-term refrigerated human platelets by the ASGPR. Evidently, different mechanisms are involved in the clearance of short-term and long-term refrigerated platelets (fig. 1).

In summary, experiments with refrigerated mouse platelets reveal the presence of functional glycosyltransferases on the platelet surface. Glycosylation of GPIb $\alpha$ on the platelet surface by externally exposed glycosyl transferases influences the circulation kinetics of platelets in vivo. Hence, this work defined an important new clearance mechanism for platelets and suggested that glycan modification can be used to influence platelet circulation kinetics. These findings further indicate that carbohydrate density and/or presentation can modulate platelet survival and that platelets are unique in having func- 
Fig. 2. Differential changes in platelets following short-term and long-term refrigeration. Platelets refrigerated for hours (shortterm refrigeration) change from smooth discs to spiky-spheres, a process induced by F-actin cytoskeleton reorganization. Clustering of the vWf receptor complex $\left(\mathrm{GPIb}_{\alpha, \beta} \mathrm{IX}\right)_{2} \mathrm{~V}$, and $\mathrm{N}$-linked glycans is initiated shortly after cooling. Prolonged platelet refrigeration (long-term refrigeration) facilitates further changes: i) Receptor and associated glycan clustering becomes maximal; ii) specific glycan residues (i.e. sialic acid and/or galactose) are removed from the platelet surface receptor(s), or receptors become cryptic due to receptor conformational changes; iii) $\alpha$-granule release causing P-selectin exposure, and/or binding of plasma proteins such as fibrinogen and/or vWf to activated $\alpha_{\mathrm{IIb}} \beta_{3}$ or $\mathrm{vWf}$ receptors.

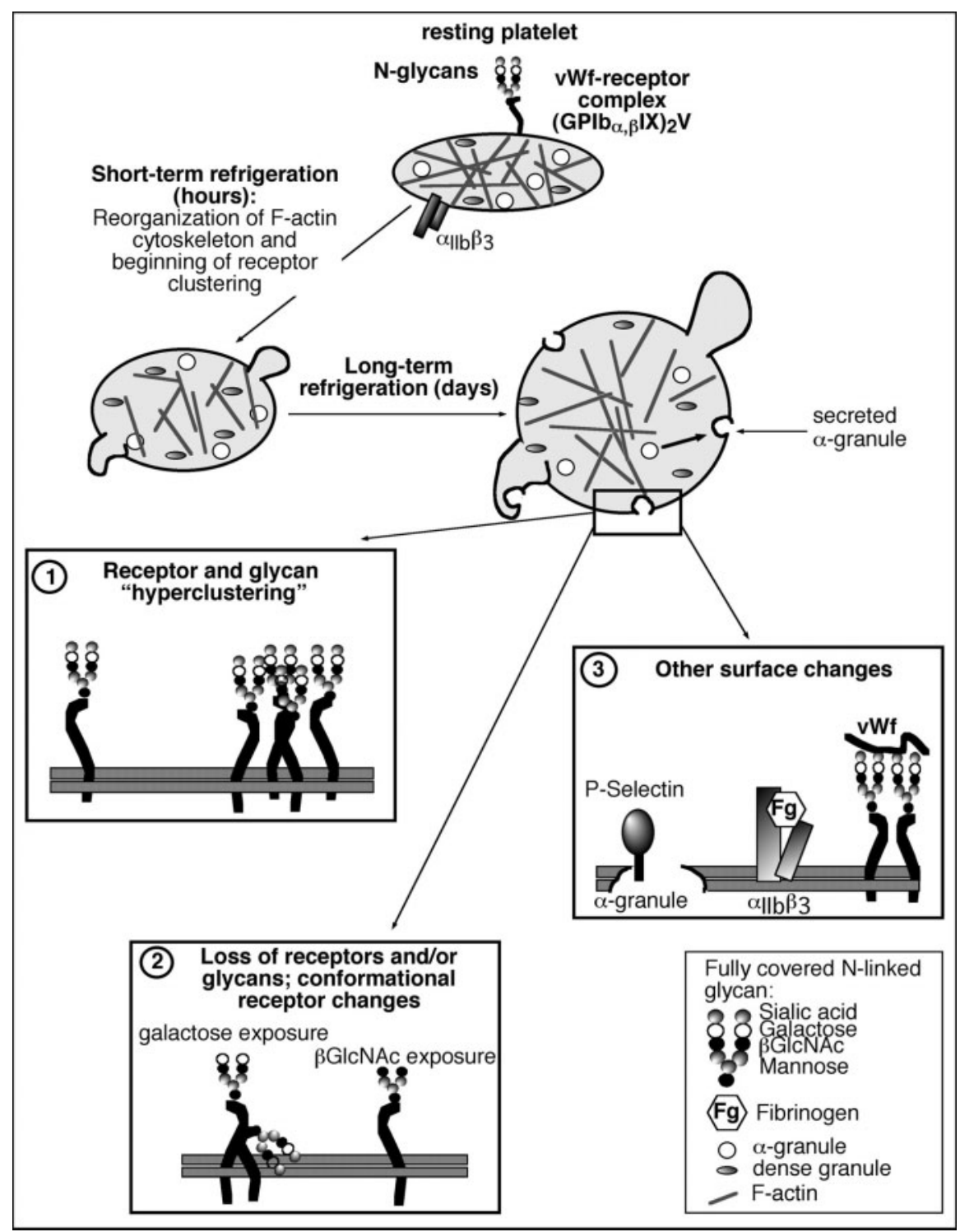

tional glycosyltransferases [89-93] expressed on their surfaces. It is tempting to speculate that reversible glycosylation of glycans on the platelet surface is a mechanism that alters platelet survival times. It is also possible that glycosylation has a role in thrombus formation and in platelet-platelet or platelet-endothelial cell adhesion.

\section{Differential Changes of Platelets Refrigerated for Short or Long Periods}

Clustering and Conformational Changes in the vWFR Complex Resting platelets rapidly change from discs to spidery forms at temperatures below $15^{\circ} \mathrm{C}$ [94-97]. Shape change occurs within minutes following refrigeration (short-term cooling) and several investigators have suggested that increased cytosolic calcium and actin remodeling are the key initiators [95, 98, 99]. One consequence of the actin rearrangement during re- frigeration is that surface vWfR complexes, which attach by GPIb $\alpha$ to underlying filaments through filamin [100-103], are redistributed from linear arrays into aggregates [37]. Since vWfR and other receptors such as $\alpha_{\operatorname{IIb}} \beta_{3}$ contain immature glycans with exposed $\beta$ GlcNAc and/or galactose moieties [29, $33,56,89,91,104]$, refrigeration can cause profound changes in the presentation of exposed glycans on the platelet surface as we have detected using specific lectins. Glycan clustering is detected early after refrigeration $[37,56]$ but may increase with long-term platelet storage in plasma (fig. 2). Platelet activation induces lipid raft aggregation [105]. Recent findings indicate that platelet exposure to cold also causes lipid raft aggregation [106], indicating that not only protein-associated glycans, but also glycolipids, may cluster in the cold. It is tempting to speculate that vWfR clustering following platelet activation or refrigeration triggers lipid raft aggregation.

Recent studies have revealed that refrigeration, in addition to clustering vWfR, also induces conformational changes in it. 
Most investigators agree that the vWfR remains intact on the surface of refrigerated platelets, although there have been some reports of shedding [107]. These results are not incompatible, as refrigeration results in the selective loss of GPIb $\alpha$ binding to some monoclonal antibodies (mAbs), but not others. Some mAbs report a significant reduction in recognition of GPIb $\alpha$ from the platelet surface even after brief refrigeration, which further increases with time [87, 108], whereas other $\mathrm{mAbs}$ report no loss following refrigeration for $\leq 2$ days [108]. However, some loss of surface receptors, specifically of GPIb $\alpha$, due to shedding or internalization, following longterm refrigeration cannot be excluded [11] (fig. 2). Fibrinogen and $\mathrm{vWf}$ binding to platelets, refrigerated long-term in plasma, may also interfere with mAbs that bind to GPIb $\alpha$ at epitopes near the vWf binding site [108] (fig. 2).

\section{Long-Term Platelet Refrigeration May Reveal New Insights into Platelet Clearance}

Like short-term refrigerated platelets, long-term refrigerated platelets are rapidly removed in the liver following transfusion [74]. Since prolonged storage in the cold increases the binding of the galactose-specific lectin RCA I (Hoffmeister et al., unpublished), we postulate that galactose residue clustering engages a different lectin-based recognition system from the previously defined $\alpha_{M} \beta_{2}-\beta$ GlcNAc interaction. Specific galactose-binding receptors include the ASGPR [109], the Kupffer cell galactose receptor [110], the scavenger receptor C-type lectin (SRCL) [111, 112], and the macrophage galactose lectin (MGL) receptor (fig. 1) [113]. Since both galactose and $\beta$ GlcNAc exposure would be expected to contribute to the clearance of refrigerated platelets, a combination of both galactosylation and sialylation would be required to rescue the circulation of long-term refrigerated platelets. Long-term refrigerated platelet clearance might also be stimulated by platelet-associated fibrinogen, which would be recognized by the $\alpha_{M}$ I-domain on macro-phages. However, fibrinogen also binds to the surface of activated platelets which circulate normally.

Additional studies are needed to determine the exact clearance mechanism of long-term refrigerated platelets. Considering the complexity of the changes induced by long-term platelet refrigeration, whether glycosylation (i.e. platelet sialylation) alone will be sufficient to overcome the rapid clearance of long-term refrigerated platelets awaits testing.

\section{Platelet Cryopreservation and Freeze-Drying}

Freeze-drying of platelets has been considered as one alternative for long-term preservation of platelets. Since the pioneering work of Klein et al. [114] in 1956, a concerted effort has been made to apply the process of freeze-drying to generate a stable platelet-based infusible hemostatic agent. Some progress has been reported in preparing lyophilized platelets that preserve platelet integrity and some functionality. One approach to preserve cell integrity applies fixation with aldehydes or similar cross-linking agents $[82,115]$. However, fixation by various cross-linking agents compromises platelet function, particularly secondary hemostatic mechanisms such as fibrinogen binding [115] and might be expected to generate neo-antigens. Fixed and lyophilized platelets have been reported to retain sufficient hemostatic function to stop bleeding [115] in thrombocytopenic animal models [116]. Clinical trials of this freeze-dried platelet product will reveal within the next few years whether or not it has useful application for transfusion on a daily basis.

Alternatively, Crowe et al. [117-119] have proposed the use of antifreeze compounds to protect freeze-dried platelet preparations. Evidence has been presented that one of these compounds, trehalose, maintains membrane microdomain organization in refrigerated and freeze-dried platelets. Platelet membranes have been shown to undergo lateral phase separation during prolonged storage in the cold $[105,120]$ causing certain surface receptors to be selectively and irreversibly incorporated into detergent resistant membrane domains. Trehalose treatment prevents this phenomenon. Once again, clinical trials are required in order to determine if this technology has feasibility for platelet transfusion practice.

Another approach for achieving long-term stabilization of platelets is long-term freezing in dimethylsulfoxide (DMSO), a cryopreservative [121-123]. Currently approved methods for platelet preservation are labor intensive and require high DMSO concentrations (5-6\%) as cryoprotectant [124]. Not surprisingly, platelet counts and functional activity decrease after freezing and thawing, and treated platelets require excessive washing to reduce the DMSO toxicity [125, 126]. 2 studies have reported that autologous platelet concentrates cryopreserved at $-180{ }^{\circ} \mathrm{C}$ in $2 \%$ DMSO and ThromboSol ${ }^{\circledR}$ (LifeCell Corp., The Woodlands, TX, USA), a platelet storage additive consisting of selected second messenger effectors (amiloride, sodium nitroprusside and adenosine), diminish platelet activation related to cooling [127]. Cryopreserved and ThromboSol-treated platelets sufficiently increased platelet counts when transfused into severely thrombocytopenic patients, indicating that freeze-dried platelets are viable to a certain extent $[128,129]$.

It remains an important concern in the development of infusion therapeutics for hemostasis that the product is both effective at inducing coagulation at wound sites and safe with respect to pathologic intravascular coagulation and no development of neo-antigens. Despite some promising clinical results, the problems of significant loss of cell number, optimal freeze rates, freezing temperature, resuspension medium and substantial impairment of in vitro functional capacity are obstacles that have yet to be overcome. There is no in vitro test which can predict platelet viability and hemostatic efficacy in 
vivo with certainty [130, 131]. Clinical trials are required to obtain information if any of the above proposed methods to cryo-preserve platelets are applicable for transfusion routine practices.

\section{Conclusions}

The reason that platelet concentrates are stored at room temperature in blood banks is because once refrigerated, platelets do not circulate. Room temperature storage results in a progressive loss of platelet functionality. Although it is widely believed that loss of discoid shape in the cold is the cause of poor survival, shape change has no adverse effects on platelet circulation kinetics or hemostatic function, and, in fact, refrigerated platelets actually retain high functionality. In an attempt to understand why refrigerated platelets circulate poorly, we defined a carbohydrate-based platelet clearance mechanism. The macrophage phagocytic integrin, $\alpha_{M} \beta_{2}$, recognizes GPIb $\alpha$-associated $\beta$ GlcNAc moieties clustered following short-term refrigeration $(2 \mathrm{~h})$, causing the ingestion and removal of platelets in vivo $[37,56]$. In an attempt to remedy this problem, we found that platelets have surface-exposed galactosyltransferase(s) that cover $\beta$ GlcNAc residues with galactose when provided with the UDP-galactose substrate. Galactosylation restores the circulation of refrigerated mouse platelets in vivo and prevents the phagocytosis of refrigerated human platelets in vitro [56]. However, it does not prevent the removal of human platelets refrigerated long-term in plasma [88]. Investigations of the relationship between vWfR clustering/conformational changes following long-term platelet refrigeration indicate that prolonged platelet refrigeration induces further profound rearrangements of platelet surface receptors and carbohydrates compared to short-term refrigeration. These changes bring additional phagocytic mechanisms into play, that cooperate with the $\alpha_{M} \beta_{2}$ receptor to remove long-term refrigerated platelets. We speculate that a combination of sialylation and galactosylation, achievable by addition of sugar substrates alone, may remedy the survival of longterm refrigerated platelets. However, a detailed analysis of the surface changes induced by long-term platelet refrigeration and their relationship to clearance mechanism(s) is required.

\section{Acknowledgments}

We thank Dr. Claes Dahlgren for discussion, and Karen Vengerow for proofreading the text. This work was supported by the American Heart Association scientist development grant, and National Institutes of Health Program Project HL56949. E.C.J. received Gothenburg University's Jubileumsfond stipend. Some of the information in this paper is part of patent applications filed by Brigham and Women's Hospital, and the intellectual property covered by those applications has been licensed to Zymequest, Inc., Beverly, MA, USA. K.M.H., and E.C.J. receive sponsored research funding from Zymequest.

\section{References}

1 Blajchman MA: Reducing the risk of bacterial contamination of cellular blood components. Dev Biol (Basel) 2000;102:183-193.

2 Bode AP: Platelet activation may explain the storage lesion in platelet concentrates. Blood Cells 1990;16:109-125; discussion 125-106.

$\checkmark 3$ Blajchman MA, Beckers EA, Dickmeiss E, Lin L, Moore G, Muylle L: Bacterial detection of platelets: current problems and possible resolutions. Transfus Med Rev 2005;19:259-272.

$\checkmark 4$ Mohammadi T, Pietersz RN, VandenbrouckeGrauls CM, Savelkoul PH, Reesink HW: Detection of bacteria in platelet concentrates: comparison of broad-range real-time $16 \mathrm{~S}$ rDNA polymerase chain reaction and automated culturing. Transfusion 2005;45:731-736.

$\checkmark 5$ McCullough J, Vesole DH, Benjamin RJ, Slichter SJ, Pineda A, Snyder E, Stadtmauer EA, LopezPlaza I, Coutre S, Strauss RG, Goodnough LT, Fridey JL, Raife T, Cable R, Murphy S, Howard Ft, Davis K, Lin JS, Metzel P, Corash L, Koutsoukos A, Lin L, Buchholz DH, Conlan MG: Therapeutic efficacy and safety of platelets treated with a photochemical process for pathogen inactivation: the SPRINT Trial. Blood 2004;104:1534-1541.

6 Hogman CF: Aspects of platelet storage. Transfus Sci 1994;15:351-355.

7 Murphy S: The efficacy of synthetic media in the storage of human platelets for transfusion. Transfus Med Rev 1999;13:153-163.

$>8$ Gulliksson H: Additive solutions for the storage of platelets for transfusion. Transfus Med 2000;10: 257-264.
9 Holme S: Platelet storage in a liquid environment. Transfus Sci 1994;15:117-130.

10 Currie LM, Harper JR, Allan H, Connor J: Inhibition of cytokine accumulation and bacterial growth during storage of platelet concentrates at 4 degrees $\mathrm{C}$ with retention of in vitro functional activity. Transfusion 1997;37:18-24.

11 Babic AM, Josefsson EC, Bergmeier W, Wagner DD, Kaufman RM, Silberstein LE, Stossel TP, Hartwig JH, Hoffmeister KM: In vitro function and phagocytosis of galactosylated platelet concentrates after long-term refrigeration. Transfusion 2007;47: 442-451.

12 Sandgren P, Shanwell A, Gulliksson H: Storage of buffy coat-derived platelets in additive solutions: in vitro effects of storage at 4 degrees $\mathrm{C}$. Transfusion 2006;46:828-834.

13 Murphy S, Gardner FH: Effect of storage temperature on maintenance of platelet viability - deleterious effect of refrigerated storage. N Engl J Med 1969;280:1094-1098.

14 Murphy S, Rebulla P, Bertolini F, Holme S, Moroff G, Snyder E, Stromberg R: In vitro assessment of the quality of stored platelet concentrates. The BEST (Biomedical Excellence for Safer Transfusion) Task Force of the International Society of Blood Transfusion. Transfus Med Rev 1994;8: 29-36.

15 Guidance for industry for platelet testing and evaluation of platelet substitute products (Internet); in Rockville MD: Center for Biologics Evaluation and Research (CBER) FDA (ed);www.fda.gov/cber/ gdlns/platelet.htm, 1999:1-7.
6 Mason KD, Carpinelli MR, Fletcher JI, Collinge JE, Hilton AA, Ellis S, Kelly PN, Ekert PG, Metcalf D, Roberts AW, Huang DC, Kile BT: Programmed anuclear cell death delimits platelet life span. Cell 2007;128:1173-1186.

17 Bergmeier W, Burger PC, Piffath CL, Hoffmeister KM, Hartwig JH, Nieswandt B, Wagner DD: Metalloproteinase inhibitors improve the recovery and hemostatic function of in vitro-aged or -injured mouse platelets. Blood 2003;102:4229-4235.

18 Brown S, Clarke M, Magowan L, Sanderson H: Constitutive death of platelets leading to scavenger receptor-mediated phagocytosis. A caspase independent program. J Biol Chem 2000;275:59875995.

19 Li J, Xia Y, Bertino AM, Coburn JP, Kuter DJ: The mechanism of apoptosis in human platelets during storage. Transfusion 2000;40:1320-1329.

20 Vance JE, Steenbergen R: Metabolism and functions of phosphatidylserine. Prog Lipid Res 2005; 44:207-234.

21 Schlegel RA, Williamson P: Phosphatidylserine, a death knell. Cell Death Differ 2001;8:551-563.

22 Bertino AM, Qi XQ, Li J, Xia Y, Kuter DJ: Apoptotic markers are increased in platelets stored at 37 degrees C. Transfusion 2003;43:857-866.

23 Perrotta PL, Perrotta CL, Snyder EL: Apoptotic activity in stored human platelets. Transfusion 2003; 43:526-535.

24 Bratosin D, Mazurier J, Debray H, Lecocq M, Boilly B, Alonso C, Moisei M, Motas C, Montreuil J: Flow cytofluorimetric analysis of young and senescent human erythrocytes probed with lectins. Evidence that sialic acids control their life span. Glycoconj J 1995;12:258-267. 
25 Bratosin D, Mazurier J, Tissier JP, Estaquier J, Huart JJ, Ameisen JC, Aminoff D, Montreuil J: Cellular and molecular mechanisms of senescent erythrocyte phagocytosis by macrophages. A review. Biochimie 1998;80:173-195.

26 Bovenschen N, Rijken DC, Havekes LM, van Vlijmen BJ, Mertens K: The B domain of coagulation factor VIII interacts with the asialoglycoprotein receptor. J Thromb Haemost 2005;3:1257-1265.

-27 Aminoff D, Bruegge WF, Bell WC, Sarpolis K, Williams R: Role of sialic acid in survival of erythrocytes in the circulation: interaction of neuraminidase-treated and untreated erythrocytes with spleen and liver at the cellular level. Proc Natl Acad Sci U S A 1977;74:1521-1524.

28 Reimers HJ, Greenberg J, Cazenave JP, Packham MA, Mustard JF: Experimental modification of platelet survival. Adv Exp Med Biol 1977;82: 231-233.

29 Steiner M, Vancura S: Asymmetrical loss of sialic acid from membrane glycoproteins during platelet aging. Thromb Res 1985;40:465-471.

30 Greenberg J, Packham MA, Cazenave JP, Reimers HJ, Mustard JF: Effects on platelet function of removal of platelet sialic acid by neuraminidase. Lab Invest 1975;32:476-484.

31 Kotze HF, van Wyk V, Badenhorst PN, Heyns AD, Roodt JP, Lotter MG: Influence of platelet membrane sialic acid and platelet-associated IgG on ageing and sequestration of blood platelets in baboons. Thromb Haemost 1993;70:676-680.

32 Ellies L, Ditto D, Levy G, Wahrenbrock M, Ginsburg D, Varki A, Le D, Marth J: Sialyltransferase ST3Gal-IV operates as a dominant modifier of hemostasis by concealing asialoglycoprotein receptor ligands. Proc Natl Acad Sci U S A 2002;99:1004210047.

33 Soslau G, Giles J: The loss of sialic acid and its prevention in stored human platelets. Thromb Res 1982;26:443-455.

34 Chernoff A, Snyder EL: The cellular and molecular basis of the platelet storage lesion: a symposium summary. Transfusion 1992;32:386-390.

35 Seghatchian J, Krailadsiri P: The platelet storage lesion. Transfus Med Rev 1997;11:130-144.

36 Scharf R, Hanfland P: Platelet storage lesions: analysis of platelet membrane glycoproteins and platelet-derived microparticles by fluorescence-activated flow cytometry. Transfus Sci 1993;14:189 194.

-37 Hoffmeister KM, Felbinger TW, Falet H, Denis CV, Bergmeier W, Mayadas TN, von Andrian UH, Wagner DD, Stossel TP, Hartwig JH: The clearance mechanism of chilled blood platelets. Cell 2003;112 87-97.

-38 Leytin V, Allen DJ, Gwozdz A, Garvey B, Freedman J: Role of platelet surface glycoprotein Ibalpha and P-selectin in the clearance of transfused platelet concentrates. Transfusion 2004;44:14871495 .

39 Snyder EL: Release of beta-thromboglobulin during storage of platelet concentrates. Vox Sang 1981; 40(suppl 1):115-116.

40 Perez-Ceballos E, Rivera J, Lozano ML, Candela MJ, Corral J, Guerrero JA, Vicente V: Evaluation of refrigerated platelet concentrates supplemented with low doses of second messenger effectors. Clin Lab Haematol 2004;26:275-286.

41 Zucker MB, Borrelli J: Viscous metamorphosis produced by chilling and by clotting failure to find specific defect of viscous metamorphosis in PTA syndrome. Thromb Diath Haemorrh 1960;4:424434.

42 Anstall HB, Hawkey CM: Observations on platelet clumping and related phenomena: a reappraisa and a clarification of terms. Transfusion 1962;2: 44-51.
43 Lindenblatt N, Menger MD, Klar E, Vollmar B: Sustained hypothermia accelerates microvascular thrombus formation in mice. Am J Physiol Heart Circ Physiol 2005;289:H2680-2687.

44 Robblee LS, Shepro D, Vecchione JJ, Valeri CR: Increased thrombin sensitivity of human platelets after storage at 4 C. Transfusion 1979;19:45-52.

45 Becker GA, Tuccelli M, Kunicki T, Chalos MK, Aster RH: Studies of platelet concentrates stored at 22 C nad 4 C. Transfusion 1973;13:61-68.

46 Rock G, Figueredo A: Metabolic changes during platelet storage. Transfusion 1976;16:571-579.

47 Choi JW, Pai SH: Influence of storage temperature on the responsiveness of human platelets to agonists. Ann Clin Lab Sci 2003;33:79-85.

48 McGill M, Brindley DC: Effects of storage on platelet reactivity to arterial subendothelium during blood flow. J Lab Clin Med 1979;94:370-380.

49 Shively JA, Gott CL, De Jongh DS: The effect of storage on adhesion and aggregation of platelets. Vox Sang 1970;18:204-215.

-50 Mondoro TH, Vostal JG: Cold temperatures re duce the sensitivity of stored platelets to disaggregating agents. Platelets 2002;13:11-20.

51 Kattlove HE, Alexander B, White F: The effect of cold on platelets. II. Platelet function after shortterm storage at cold temperatures. Blood 1972;40: 688-696.

52 Zhang JN, Wood J, Bergeron AL, McBride L, Ball C, Yu Q, Pusiteri AE, Holcomb JB, Dong JF: Effects of low temperature on shear-induced platelet aggregation and activation. J Trauma 2004;57:216223

53 Han Q, Chen J, Peng Y, Bergeron AL, Liu L, Dong J, Lopez JA: The mechanism of cold-induced platelet hyperfunction. Blood (ASH Annual Meeting Abstracts) 2005;106:1651.

54 Berger G, Hartwell DW, Wagner DD: P-Selectin and platelet clearance. Blood 1998;92:4446-4452.

55 Michelson A, Barnard M, Hechtman H, MacGregor $\mathrm{H}$, Connolly $\mathrm{R}$, Loscalzo J, Valeri C: In vivo tracking of platelets: circulating degranulated platelets rapidly lose suface $\mathrm{P}$-selectin but continue to circulate and function. Proc Natl Acad Sci U S A 1996;93:11877-11882.

56 Hoffmeister KM, Josefsson EC, Isaac NA, Clausen H, Hartwig JH, Stossel TP: Glycosylation restores survival of chilled blood platelets. Science 2003;301: 1531-1534.

57 Italiano JE Jr, Bergmeier W, Tiwari S, Falet H, Hartwig JH, Hoffmeister KM, Andre P, Wagner DD, Shivdasani RA: Mechanisms and implications of platelet discoid shape. Blood 2003;101:47894796.

58 Rao AK, Murphy S: Secretion defect in platelets stored at 4 degrees C. Thromb Haemost 1982;47: 221-225.

59 Zappia GC, Steiner M, Ando Y, Baldini M: Effect of chilling on platelet cyclic adenosine 3:5-monophosphate and adenylate cyclase activity. Transfusion 1976;16:122-129.

60 Heldt HW, Klingenberg M: Differences between the reactivity of endogenous and exogenous adenine nucleotides in mitochondria as studied at low temperature. Eur J Biochem 1968;4:1-8.

61 Penefsky HS, Warner RC: Partial resolution of the enzymes catalyzing oxidative phosphorylation. VI Studies on the mechanism of cold inactivation of mitochondrial adenosine triphosphatase. J Biol Chem 1965;240:4694-4702.

62 Kahn RA, Staggs SD, Miller WV, Heaton WA: Re covery, lifespan, and function of CPD-Adenine (CPDA-1) platelet concentrates stored for up to 72 hours at 4 C. Transfusion 1980;20:498-503.
63 Filip DJ, Aster RH: Relative hemostatic effectiveness of human platelets stored at 4 degrees and 22 degrees C. J Lab Clin Med 1978;91:618-624.

64 Slichter SJ, Harker LA: Preparation and storage of platelet concentrates. II. Storage variables influencing platelet viability and function. Br J Haematol 1976;34:403-419.

65 Handin RI, Valeri CR: Hemostatic effectiveness of platelets stored at 22 degrees C. N Engl J Med 1971;285:538-543.

66 Valeri CR: Circulation and hemostatic effectiveness of platelets stored at $4 \mathrm{C}$ or $22 \mathrm{C}$ : studies in aspirintreated normal volunteers. Transfusion 1976;16: 20-23.

67 Kattlove HE: Platelet preservation-what temperature? A rationale for strategy. Transfusion 1974;14: 328-330.

68 Blajchman MA, Lee DH: The thrombocytopenic rabbit bleeding time model to evaluate the in vivo hemostatic efficacy of platelets and platelet substitutes. Transfus Med Rev 1997;11:95-105.

69 Rothwell SW, Maglasang P, Krishnamurti C: Survival of fresh human platelets in a rabbit mode as traced by flow cytometry. Transfusion 1998;38: 550-556.

70 Tang RC, Huang CY, Pei XP, Chen BA, Li CP, Sh GY: Evaluation of the effects of glycosylation on in vivo survival of cold-storage human platelets by using rabbit model. Zhongguo Shi Yan Xue Ye Xue Za Zhi 2005;13:1113-1116.

71 Pei XP, Chen BA, Huang CY, Li CP, Shi GY, Xiao JY, Gao C, Ding JH, Fei F, Wang J, Sun YY, Cheng J, Zhao G: Cold storage of rabbit platelet suspension by adding uridine diphosphate galactose Zhongguo Shi Yan Xue Ye Xue Za Zhi 2006;14: 1244-1247.

72 Huang CY, Tang RC, Cai L, Cui Y, Liu L: Cold storage of platelet suspension by adding trehalose Zhongguo Shi Yan Xue Ye Xue Za Zhi 2005;13 904-906.

73 Valeri CR, Ragno G, Marks PW, Kuter DJ, Rosenberg RD, Stossel TP: Effect of thrombopoietin alone and a combination of cytochalasin B and ethylene glycol bis(beta-aminoethyl ether) N,N'tetraacetic acid-AM on the survival and function of autologous baboon platelets stored at 4 degrees $\mathrm{C}$ for as long as 5 days. Transfusion 2004;44:865-870.

74 Valeri CR, Giorgio A, Macgregor H, Ragno G: Circulation and distribution of autotransfused fresh, liquid-preserved and cryopreserved baboon platelets. Vox Sang 2002;83:347-351.

75 Valeri CR, MacGregor H, Barnard MR, Summaria L, Michelson AD, Ragno G: Survival of baboon biotin-X-N-hydroxysuccinimide and (111)In-oxinelabelled autologous fresh and lyophilized reconstituted platelets. Vox Sang 2005;88:122-129.

76 Harker LA, Marzec UM, Hunt P, Kelly AB, Tomer A, Cheung E, Hanson SR, Stead RB: Dose-response effects of pegylated human megakaryocyte growth and development factor on platelet production and function in nonhuman primates. Blood 1996;88:511-521.

77 Harker LA, Hunt P, Marzec UM, Kelly AB, Tomer A, Hanson SR, Stead RB: Regulation of platelet production and function by megakaryocyte growth and development factor in nonhuman primates. Blood 1996;87:1833-1844.

78 Malpass TW, Hanson SR, Savage B, Hessel EA 2nd, Harker LA: Prevention of acquired transient defect in platelet plug formation by infused prostacyclin. Blood 1981;57:736-740.

79 Krishnamurti C, Maglasang P, Rothwell SW: Reduction of blood loss by infusion of human platelets in a rabbit kidney injury model. Transfusion 1999 39:967-974. 
80 Leytin V, Allen DJ, Mody M, Rand ML, Hannach B, Garvey B, Freedman J: A rabbit model for monitoring in vivo viability of human platelet concentrates using flow cytometry. Transfusion 2002;42: 711-718.

81 Macchiarini F, Manz MG, Palucka AK, Shultz LD: Humanized mice: are we there yet? J Exp Med 2005;202:1307-1311.

82 Read MS, Reddick RL, Bode AP, Bellinger DA, Nichols TC, Taylor K, Smith SV, McMahon DK, Griggs TR, Brinkhous KM: Preservation of hemostatic and structural properties of rehydrated lyophilized platelets: potential for long-term storage of dried platelets for transfusion. Proc Nat Acad Sci U S A 1995;92:397-401.

83 Tablin F, Walker NJ, Klein SD, Field CL, Crowe JH: Animal models for studies on cold-induced platelet activation in human beings. J Lab Clin Med 2000;135:339-346.

84 Dewanjee MK, Belinskiy VV, Holland JF, Kapadvanjwala M, Wu SM, Novak S, Hsu LC, Sanchez J, Dewanjee S, Serafini AN, Duncan RC, Sfakianakis GN: Effect of thoracotomy and cardiopulmonary bypass on activated platelet and neutrophil dynamics and platelet emboli in a pig model. J Thromb Thrombolysis 1996;3:195-208.

85 Zoghbi SS, Thakur ML, Sostman HD, Greenspan RH, Gottschalk A: Indium-111-oxinate labeled swine platelets and their survival in vivo. Lab Anim Sci 1988;38:444-447.

86 Josefsson EC, Gebhard HH, Stossel TP, Hartwig JH, Hoffmeister KM: The macrophage alphaMbeta2 integrin alphaM lectin domain mediates the phagocytosis of chilled platelets. J Biol Chem 2005; 280:18025-18032.

87 Badlou BA, Spierenburg G, Ulrichts H, Deckmyn H, Smid WM, Akkerman JW: Role of glycoprotein Ibalpha in phagocytosis of platelets by macrophages. Transfusion 2006;46:2090-2099.

88 Slichter SJ, Wandall HH, Hoffmeister KM: In vivo studies of autologous platelets stored at room temperture $22{ }^{\circ} \mathrm{C}, 4{ }^{\circ} \mathrm{C}$, and $4{ }^{\circ} \mathrm{C}$ with galactosylation. Blood (ASH Annual Meeting Abstracts) 2006;108: 580.

89 Rodriguez P, Bello O, Tablante A, Apitz-Castro R: Galactosylation of endogenous proteins from human platelets. Biochem Med Metab Biol 1988; 40:151-161.

90 Rodriguez P, Durante P: Characterization of a protein: glucosyltransferase activity in human platelets. Biochem Med Metab Biol 1990;43:147-158.

91 Bauvois B, Cacan R, Nurden AT, Caen J, Montreuil $\mathrm{J}$, Verbert A: Membrane glycoprotein IIb is the major endogenous acceptor for human platelet ectosialyltransferase. FEBS Lett 1981;125:277-281.

92 Bauvois B, Cacan R, Fournet B, Caen J, Montreuil $\mathrm{J}$, Verbert A: Discrimination between activity of (alpha 2-3)-sialyltransferase and (alpha 2-6)-sialyltransferase in human platelets using p-nitrophenylbeta-D-galactoside as acceptor. Eur J Biochem 1982;121:567-572.

93 Hopper K, Semler A, Chapman G, Davey R: Release of galactosyltransferase from human platelets and a subset of monocytes in culture. Blood 1986; 68:176-172.

94 Zucker MB, Borrelli J: Reversible alterations in platelet morphology produced by anticoagulants and by cold. Blood 1954;9:602-608.

95 Winokur R, Hartwig JH: Mechanism of shape change in chilled human platelets. Blood 1995;85: 1796-1804.

96 Kubisz P, Klener P: Platelet shape change induced by cold and the retraction of reptilase clots. Acta Univ Carol Med (Praha) 1976;22:9-17.
97 White JG, Krumwiede M: Influence of cytochalasin $\mathrm{B}$ on the shape change induced in platelets by cold. Blood 1973;41:823-832.

98 Oliver AE, Tablin F, Walker NJ, Crowe JH: The internal calcium concentration of human platelets increases during chilling. Biochim Biophys Acta 1999;1416:349-360.

99 Hoffmeister KM, Falet H, Toker A, Barkalow KL, Stossel TP, Hartwig JH: Mechanisms of cold-induced platelet actin assembly. J Biol Chem 2001; 276:24751-24759.

100 Okita JR, Pidard D, Newman PJ, Montgomery RR, Kunicki TJ: On the association of glycoprotein Ib and actin-binding protein in human platelets. J Cell Biol 1985;100:317-321.

101 Fox JE, Aggerbeck LP, Berndt MC: Structure of the glycoprotein Ib.IX complex from platelet membranes. J Biol Chem 1988;263:4882-4890.

102 Nakamura F, Pudas R, Heikkinen O, Permi P, Kilpelainen I, Munday AD, Hartwig JH, Stossel TP, Ylanne J: The structure of the GPIb-filamin A complex. Blood 2005.

103 Ezzell R, Kenney D, Egan S, Stossel T, Hartwig J: Linkage of the membrane glycoprotein GPIb to the actin cytoskeleton by a defined domain of actin-binding protein (ABP) in resting and thrombin-activated human platelets. J Cell Biol 1987; 105:211a

104 Ganguly P, Fossett NG: The role of sialic acid in the activation of platelets by wheat germ agglutinin. Blood 1984;63:181-187.

105 Gousset K, Tsvetkova NM, Crowe JH, Tablin F: Important role of raft aggregation in the signaling events of cold-induced platelet activation. Biochim Biophys Acta 2004:1660:7-15.

106 Gousset K, Wolkers W, Tsvetkova N, Oliver A, Field C, Walker N, Crowe J, Tablin F: Evidence for a physiological role for membrane rafts in human platelets. J Cell Physiol 2002;190:117-128.

107 Bode AP, Knupp CL: Effect of cold storage on platelet glycoprotein Ib and vesiculation. Transfusion 1994;34:690-696.

108 Josefsson EC, Bergmeier W, Wagner DD, Stossel TP, Hartwig JH, Hoffmeister KM: Differential changes in platelet VWF receptor following refrigeration for short or long periods. Blood (ASH Annual Meeting Abstracts) 2005;106:3564.

109 Ashwell G, Harford J: Carbohydrate-specific receptors of the liver. Annu Rev Biochem 1982;51: 531-554.

110 Hoyle GW, Hill RL: Molecular cloning and sequencing of a cDNA for a carbohydrate binding receptor unique to rat Kupffer cells. J Biol Chem 1988;263:7487-7492.

111 Nakamura K, Funakoshi H, Tokunaga F, Nakamura T: Molecular cloning of a mouse scavenger receptor with C-type lectin (SRCL)(1), a novel member of the scavenger receptor family. Biochim Biophys Acta 2001:1522:53-58.

112 Nakamura K, Funakoshi H, Miyamoto K, Tokunaga F, Nakamura T: Molecular cloning and functional characterization of a human scavenger receptor with C-type lectin (SRCL), a novel member of a scavenger receptor family. Biochem Biophys Res Commun 2001;280:1028-1035.

113 Coombs PJ, Taylor ME, Drickamer K: Two categories of mammalian galactose-binding receptors distinguished by glycan array profiling. Glycobiology 2006;16:1C-7C.

114 Klein E, Toch R, Farber S, Freeman G, Fiorentino R: Hemostasis in thrombocytopenic bleeding following infusion of stored, frozen platelets. Blood 1956;11:693-699.

-115 Fischer TH, Bode AP, Parker BR, Russell KE, Bender DE, Ramer JK, Read MS: Primary and secondary hemostatic functionalities of rehydrated, lyophilized platelets. Transfusion 2006;46: 1943-1950.
116 Bode AP, Fischer TH: Lyophilized platelets: fifty years in the making. Artif Cells Blood Substit Immobil Biotechnol 2007;35:125-133.

117 Crowe J, Tablin F, Wolkers W, Gousset K, Tsvetkova N, Ricker J: Stabilization of membranes in human platelets freeze-dried with trehalose. Chem Phys Lipids 2003;122:41-52.

118 Crowe JH, Tablin F, Tsvetkova N, Oliver AE, Walker N, Crowe LM: Are lipid phase transitions responsible for chilling damage in human platelets? Cryobiology 1999;38:180-191.

119 Tablin F, Oliver A, Walker N, Crowe L, Crowe J Membrane phase transition of intact human platelets: correlation with cold-induced activation J Cell Phys 1996;168:305-313.

120 Tablin F, Wolkers W, Walker N, Oliver A Tsvetkova N, Gousset K, Crowe L, Crowe J: Mem-brane reorganization during chilling: implications for long-term stabilization of platelets. Cryobiology 2001;43:114-123.

121 Sputtek A: Kryokonservierung von Blutzellen un hämatopoetischen Zellen; in Mueller-Eckhardt C, Kiefel V (eds): Transfusionsmedizin. Berlin, Springer, 2004, pp. 133-144.

122 Sputtek A: Cryopreservation of red cells and platelets; in Day JG, Stacey G (eds): Cryopreservation and Freeze Drying Protocols. Totowa, Humana Press, 2007, pp. 281-299.

123 Sputtek A, Sputtek R: Cryopreservation in transfusion medicine and haematology; in Fuller BJ, Lane N, Benson EE (eds): Life in a Frozen State. Boca Raton, CRC Press, 2004, pp. 483-504.

124 Walker RH: Technical manual; American Association of Blood Banks, Bethesda, USA, 1993, pp 733-738.

125 Melaragno AJ, Carciero R, Feingold H, Talarico L, Weintraub L, Valeri CR: Cryopreservation of human platelets using $6 \%$ dimethyl sulfoxide and storage at -80 degrees C. Effects of 2 years of frozen storage at -80 degrees $\mathrm{C}$ and transportation in dry ice. Vox Sang 1985;49:245-258.

126 Balduini CL, Mazzucco M, Sinigaglia F, Grignani G, Bertolino G, Noris P, Pacchiarini L, Torti M, Salvaneschi L: Cryopreservation of human platelets using dimethyl sulfoxide and glycerol-glucose: effects on 'in vitro' platelet function. Haematologica 1993;78:101-104

127 Connor J, Currie LM, Allan H, Livesey SA: Recovery of in vitro functional activity of platele concentrates stored at 4 degrees $\mathrm{C}$ and treated with second-messenger effectors. Transfusion 1996;36:691-698.

128 Pedrazzoli P, Noris P, Perotti C, Schiavo R, Ponchio L, Belletti S, Da Prada GA, Balduini CL, Salvaneschi L, Robustelli Della Cuna G, Siena S: Transfusion of platelet concentrates cryopreserved with ThromboSol plus low-dose dimethylsulphoxide in patients with severe thrombocytopenia: a pilot study. Br J Haematol 2000;108:653-659.

129 Vadhan-Raj S, Kavanagh JJ, Freedman RS, Folloder J, Currie LM, Bueso-Ramos C, Verschraegen $\mathrm{CF}$, Narvios $\mathrm{AB}$, Connor J, Hoots WK, Broemeling LD, Lichtiger B: Safety and efficacy of transfusions of autologous cryopreserved platelets derived from recombinant human thrombopoietin to support chemotherapy-associated severe thrombocytopenia: a randomised cross-over study. Lancet 2002;359:2145-2152.

130 Holme S: Storage and quality assessment of platelets. Vox Sang 1998;74(suppl 2):207-216.

131 Vostal JG, Reid TJ, Mondoro TH: Summary of a workshop on in vivo efficacy of transfused platelet components and platelet substitutes. Transfusion 2000;40:742-750 